\title{
INFLUENCE OF DIFFERENT TEMPERATURES AND AIRFLOWS ON DRYING OF NATURAL AND PULPED COFFEE
}

\author{
Guilherme E. Alves ${ }^{1}$, Flávio M. Borém ${ }^{1}$, Ednilton T. Andrade ${ }^{1}$, Éder P. Isquierdo², \\ Valdiney C. Siqueira ${ }^{3}$, Camila de A. Dias ${ }^{1 *}$
}

${ }^{1 *}$ Corresponding author. Universidade Federal de Lavras/ Lavras - MG, Brasil.

E-mail: camila.almeidadias@gmail.com | ORCID ID: https://orcid.org/0000-0001-8422-7867

\section{KEYWORDS}

Coffea arabica L., mathematical modeling, drying rate.

\begin{abstract}
This study aimed to evaluate drying kinetics for natural and pulped coffee, using different temperatures and drying airflows. For the conduction of the experiment, coffee fruits (Coffea arabica L. cv. Topázio) were harvested manually, selecting only ripe fruits and subsequent to the hydraulic separation. For drying the coffee, use a mechanical dryer with two temperatures $\left(40\right.$ and $\left.45^{\circ} \mathrm{C}\right)$ and four drying air streams $\left(24 ; 60 ; 96\right.$ and $132 \mathrm{~m}^{3} . \mathrm{min}^{-}$ ${ }^{1} \cdot \mathrm{m}^{-2}$ ). Twelve models for employees to describe the drying kinetics of coffees. Among the models used to describe the drying process of natural coffee and pulped coffee, according to the results of the coefficient of determination, relative mean error, standard deviation of estimates and distribution of waste distribution, proposed model for the only one that presents fit for all as conditions study. The temperature of $45^{\circ} \mathrm{C}$ and the airflows of 96 and $132 \mathrm{~m}^{3} \cdot \mathrm{min}^{-1} \cdot \mathrm{m}^{-2}$ provide the shortest drying times regardless of the coffee processing type.
\end{abstract}

\section{INTRODUCTION}

Brazil is a leader in the world market for production and export of raw coffee. It has advanced technologies for production and crop protection and is prepared to offer high harvest yields. However, developing technologies that reduce drying time and energy consumption requires a more sustainable solution, which makes drying one of the main bottlenecks in Brazilian coffee farming (Borém, 2013).

Technology currently available for drying coffee only increases drying rates by increasing temperature or airflow. However, coffee mass temperatures above $40{ }^{\circ} \mathrm{C}$ cause thermal damage, depreciating drink quality (Isquierdo, 2013).

Drying kinetics of agricultural products has great importance to select suitable temperatures and times required for an adequate drying process and to obtain a final product of higher quality (Avhad \& Marchetti, 2016).

An alternative to increase drying rates without exceeding maximum tolerable temperatures for coffee is drying airflows higher than those used commercially. It is necessary to have experimental tests that provide data for process simulation before they are used on a commercial scale.
Several models have been fitted to describe drying process of hygroscopic capillary-porous products. Among these models are Midilli, Page, Thompson, Verma, Henderson and Pabis, modified Henderson and Pabis, twoterm, two-term exponential, Newton, Wang and Sing, and Valcam (Corrêa et al., 2014; Goneli et al., 2009; Isquierdo, 2013; Resende et al., 2009; Siqueira et al., 2013).

This research aimed to study the drying kinetics in a thin layer of coffee (Coffea arabica L.), cultivar Topázio, to adjust different mathematical models to the experimental values as a function of processing type, temperature, and drying airflow, as well as checking for differences in total drying time with each studied airflow.

\section{MATERIAL AND METHODS}

This study was carried out in the Laboratory of Agricultural Products Processing, Department of Engineering, Federal University of Lavras (UFLA), Minas Gerais State, Brazil.

The experiment was conducted with manually harvested coffee (Coffea arabica L. cv. Topázio) fruits. Only ripe or "cherry" fruits were selected from UFLA's

\footnotetext{
${ }^{1}$ Universidade Federal de Lavras/ Lavras - MG, Brasil.

${ }^{2}$ Universidade do Estado de Mato Grosso/ Cáceres - MT, Brasil.

${ }^{3}$ Universidade Federal da Grande Dourados/ Dourados - MS, Brasil. 
experimental field. After harvesting, fruits were subjected to hydraulic separation to remove fruits of a low specific mass (dry, immature, insect-damaged, and malformed), followed by manual selection to remove immature and overripe fruits. Then, part of the fruits was taken to dryers, consisting of "natural" portion or processed through dry route, while the other part was peeled and subjected to spontaneous fermentation in water to remove mucilage under ambient conditions for 20 hours, forming the portion of pulped coffee processed by wet route. After this period, parchment coffees were washed under running water until mucilage was removed entirely and, afterward, a pulped coffee lot was sent for drying.

Drying was carried out in mechanical fixed-layer dryers, which allow flow and temperature control of drying air with precision until coffee reaches $0.125 \pm 0.005$ (db). Coffee fruits were weighed during the entire drying process for subsequent preparation of curves, drying times, and rates.

Each dryer consisted of four removable trays with perforated bottoms. Four circular-section tubes with a diameter of $0.125 \mathrm{~m}$ and a height of $0.17 \mathrm{~m}$, located on a plenum for uniform airflow, were placed on each tray. After processing, this coffee was placed inside these tubes, with approximately 0.17 and $0.315 \mathrm{~kg}$ each sample, corresponding to a thin layer of 0.025 and $0.043 \mathrm{~m}$ of pulped and natural coffee, respectively.

At the beginning and end of drying process, coffee fruit and parchment coffee moisture contents were determined using standard oven method at $105 \pm 3{ }^{\circ} \mathrm{C}$ for 24 hours, according to the Rules for Seed Testing (Brasil, 2009). Yet for processed dry coffee, moisture content was determined by the ISO 6673 standard method (International Organization for Standardization - ISO, 2003). After obtaining mass and initial moisture content of coffee fruits and parchment coffee, drying was monitored by gravimetric method (loss of mass) until reaching a content of $0.125 \pm 0.005(\mathrm{db})$, using a $0.01-\mathrm{g}$ analytical scale, according to the equation below:

$$
U_{t}=\frac{M a_{i}-\left(M t_{i}-M t_{t}\right)}{M_{m s}}
$$

Where:

$\mathrm{U}_{\mathrm{t}}$ is the moisture content at time $\mathrm{t}\left(\mathrm{kg}\right.$ water $\mathrm{kg}^{-1}$ dry matter, $\mathrm{db}$ );

$\mathrm{Ma}_{\mathrm{i}}$ is the initial water mass $(\mathrm{kg})$;

$\mathrm{Mt}_{\mathrm{i}}$ is the initial total mass $(\mathrm{kg})$;

$\mathrm{Mt}_{\mathrm{t}}$ is the total mass at time $\mathrm{t}(\mathrm{kg})$,

$\mathrm{M}_{\mathrm{ms}}$ is the dry matter mass $(\mathrm{kg})$.

Water evaporation speed was determined from the drying rate of the product, according to the following expression:

$$
\mathrm{DR}=\frac{\mathrm{U}_{\mathrm{prev}}-\mathrm{U}_{\mathrm{c}}}{\Delta \mathrm{t}}
$$

Where:

$\mathrm{DR}$ is the drying rate $\left(\mathrm{g}\right.$ water $\mathrm{kg}^{-1}$ dry matter $\left.\mathrm{h}^{-1}\right)$;

$\mathrm{U}_{\text {prev }}$ is the moisture content in the previous time ( $\mathrm{g}$ water $\mathrm{kg}^{-1}$ dry matter, $\mathrm{db}$ );

$\mathrm{U}_{\mathrm{c}}$ is the current moisture content ( $\mathrm{g}$ water $\mathrm{kg}^{-1}$ dry matter, db),

$\Delta \mathrm{t}$ is the time interval between weighings (h).

Drying system consisted of three fixed-layer dryers, which allowed controlling drying-airflow and temperature with precision, using an electronic panel.

Drying airspeed was measured using a paddle anemometer. It was regulated and kept constant for all treatments at $0.4,1.0,1.6$, and $2.2 \mathrm{~m} \mathrm{~s}^{-1}$, corresponding to flows of $24,60,96$, and $132 \mathrm{~m}^{3} \mathrm{~min}^{-1} \mathrm{~m}^{-2}$, respectively. Two temperatures were used for drying air $\left(40\right.$ and $\left.45^{\circ} \mathrm{C}\right)$, which were monitored using mercury thermometers placed in the middle of coffee mass. Different drying conditions were obtained depending on combination among processing, temperature, and drying airflows.

Moisture ratio (MR) is essential for drying data analysis since it describes different thin-layer drying models. During drying, it was determined as in [eq. (3)], as a function of evaluated variables. Values of MR as a function of drying time for all tested conditions were fitted to models used to describe coffee drying kinetics, as shown in Table 1.

$$
M R=\frac{U-U_{e}}{U_{i}-U_{e}}
$$

Where:

MR is the moisture ratio;

$\mathrm{U}$ is the moisture content of the product at time $\mathrm{t}$ (decimal, db);

$\mathrm{U}_{\mathrm{e}}$ is the equilibrium moisture content of the product (decimal, db), and

$\mathrm{U}_{\mathrm{i}}$ is the initial moisture content of the product (decimal, db).

Hygroscopic equilibrium moisture content was calculated by eqs (4) and (5) for natural and pulped coffee (Afonso Júnior, 2001), respectively.

$$
\begin{aligned}
& \mathrm{U}_{\mathrm{e}}=\left(2.0222+0.0288 \mathrm{~T}-18.7397 . \mathrm{RH}^{8.6181}\right)^{-2.1385} \\
& \mathrm{U}_{\mathrm{e}}=\left(2.9636+0.0530 \mathrm{~T}-10.7837 . \mathrm{RH}^{4.5136}\right)^{-1.6503}
\end{aligned}
$$

Where:

Ue is the equilibrium moisture content of the product (decimal, db);

$\mathrm{T}$ is the drying air temperature $\left({ }^{\circ} \mathrm{C}\right)$,

$\mathrm{RH}$ is the relative humidity of the drying air (decimal)

Mathematical models frequently used to represent the drying kinetics of agricultural products were fitted to the experimental data of coffee MR obtained for each type of processing and drying air condition (Table 1). 
TABLE 1. Mathematical models used to predict drying kinetics.

\begin{tabular}{ll}
\hline Model designation & Model \\
\hline Dois termos & $M R=a \cdot \exp \left(-\mathrm{k}_{0} \cdot \mathrm{t}\right)+\mathrm{b} \cdot \exp \left(-\mathrm{k}_{1} \cdot \mathrm{t}\right)$ \\
Exponencial de dois termos & $\mathrm{MR}=\mathrm{a} \cdot \exp (-\mathrm{k} \cdot \mathrm{t})+(1-\mathrm{a}) \exp (-\mathrm{k} \cdot \mathrm{a} \cdot \mathrm{t})$ \\
Henderson \& Pabis modificado & $\mathrm{MR}=\mathrm{a} \cdot \exp (-\mathrm{k} \cdot \mathrm{t})+\mathrm{b} \cdot \exp \left(-\mathrm{k}_{0} \cdot \mathrm{t}\right)+\mathrm{c} \cdot \exp \left(-\mathrm{k}_{1} \cdot \mathrm{t}\right)$ \\
Henderson \& Pabis & $\mathrm{MR}=\mathrm{a} \cdot \exp (-\mathrm{k} \cdot \mathrm{t})$ \\
Midilli & $\mathrm{MR}=\mathrm{a} \cdot \exp \left(-\mathrm{k} \cdot \mathrm{t}^{\mathrm{n}}\right)+\mathrm{b} \cdot \mathrm{t}$ \\
Newton & $\mathrm{MR}=\exp (-\mathrm{k} \cdot \mathrm{t})$ \\
Page & $\mathrm{MR}=\exp \left(-\mathrm{k} \cdot \mathrm{t}^{\mathrm{n}}\right)$ \\
Thompson & $\mathrm{MR}=\exp \left\{\left[-\mathrm{a}-\left(-\mathrm{a}^{2}+4 \cdot \mathrm{b} \cdot \mathrm{t}\right)^{0,5} \cdot(2 \cdot \mathrm{b})^{-1}\right\}\right.$ \\
Verma & $\mathrm{MR}=-\mathrm{a} \cdot \exp (-\mathrm{k} \cdot \mathrm{t})+(1-\mathrm{a}) \exp \left(-\mathrm{k}_{1} \cdot \mathrm{t}\right)$ \\
Wang e Sing & $\mathrm{MR}=1+\mathrm{a} \cdot \mathrm{t}+\mathrm{b} \cdot \mathrm{t}^{2}$ \\
Valcam & $\mathrm{MR}=\mathrm{a}+\mathrm{b} \cdot \mathrm{t}+\mathrm{c} \cdot \mathrm{t}^{1,5}+\mathrm{d} \cdot \mathrm{t}^{2}$ \\
Modelo Proposto & $\mathrm{MR}=\left(\mathrm{a} \cdot \exp \left(\mathrm{k}_{0} \cdot \mathrm{t}\right)^{\mathrm{n}}\right) \cdot\left(\mathrm{b}+\exp \cdot\left(\mathrm{k}_{1} \cdot \mathrm{t}\right)^{\mathrm{n}}\right)^{-1}$
\end{tabular}

MR - moisture ratio; $\mathrm{t}$ - drying time $(\mathrm{h}) ; \mathrm{k}, \mathrm{k}_{0}$, and $\mathrm{k}_{1}$ - drying constants; $\mathrm{a}, \mathrm{b}, \mathrm{c}, \mathrm{d}$, and $\mathrm{n}$ - model coefficients.

Non-linear regression analyses were performed by the Gauss-Newton method using the software STATISTICA $7.0^{\circledR}$ (Statsoft, Tulsa, USA) to adjust mathematical models. The best model was chosen based on statistical parameters, namely: standard deviation of estimates (SD), relative mean error (P), coefficient of determination $\left(\mathrm{r}^{2}\right)$, and trend of distribution of residues. The standard deviation of estimates and relative mean error were calculated by eqs (18) and (19), respectively.

$$
\begin{aligned}
& \mathrm{SD}=\sqrt{\sum(\mathrm{Y}-\hat{\mathrm{Y}})^{2} / \mathrm{DF}} \\
& \mathrm{P}=\left[(100 / \mathrm{n}) \sum[(\mathrm{Y}-\hat{\mathrm{Y}} \mathrm{I} / \mathrm{Y})]\right.
\end{aligned}
$$

Where:

$\mathrm{SD}$ is the standard deviation of estimates (decimal);

$\mathrm{Y}$ is the value observed experimentally;

$\hat{\mathrm{Y}}$ is the value calculated by the model;
DF is the degrees of freedom of the model;

$\mathrm{P}$ is the relative mean error (\%), and

$\mathrm{n}$ is the number of observed data.

Drying time was evaluated in a completely randomized design, in a $2 \times 4$ factorial scheme for each coffee processing system. Treatments consisted of two temperatures and four drying airflows, with four repetitions. Data were subjected to analysis of variance (ANOVA), and means were compared by Tukey's test at 5\% significance using the SISVAR ${ }^{\circledR}$ software (Ferreira, 2011).

\section{RESULTS AND DISCUSSION}

Table 2 shows the drying times, initial moisture content of coffee fruits and parchment coffee, final moisture content of processed natural and pulped coffee, and mean and maximum drying rates as a function of temperature and drying airflow.

TABLE 2. Type of processing (natural - NAT and pulped - CD), airflow, drying time, initial and final moisture content, mean

\begin{tabular}{|c|c|c|c|c|c|c|c|}
\hline \multirow[t]{2}{*}{ Processing } & \multirow{2}{*}{$\begin{array}{l}\text { Tem } \\
\left({ }^{\circ} \mathrm{C}\right)\end{array}$} & \multirow{2}{*}{$\begin{array}{c}\text { Airflow } \\
\left(\mathrm{m}^{3} \min ^{-1} \mathrm{~m}^{-2}\right)\end{array}$} & \multirow[t]{2}{*}{ Drying time (h) } & \multicolumn{2}{|c|}{$\begin{array}{l}\text { Moisture content } \\
(\mathrm{db})\end{array}$} & \multicolumn{2}{|c|}{$\begin{array}{l}\text { Drying rate } \\
\left(\mathrm{g} \mathrm{kg}^{-1} \mathrm{~h}^{-1}\right)\end{array}$} \\
\hline & & & & Initial & Final & Mean & Maximum \\
\hline \multirow{8}{*}{ NAT } & \multirow{4}{*}{40} & 24 & 73.20 & 2.19 & 0.125 & 39.84 & 209.25 \\
\hline & & 60 & 71.06 & 2.19 & 0.125 & 41.77 & 217.17 \\
\hline & & 96 & 67.92 & 2.19 & 0.125 & 42.44 & 223.33 \\
\hline & & 132 & 66.10 & 2.20 & 0.125 & 44.16 & 234.27 \\
\hline & \multirow{4}{*}{45} & 24 & 47.93 & 1.93 & 0.125 & 43.78 & 222.09 \\
\hline & & 60 & 45.84 & 1.93 & 0.125 & 45.57 & 240.23 \\
\hline & & 96 & 44.08 & 1.96 & 0.125 & 47.57 & 239.78 \\
\hline & & 132 & 44.46 & 1.95 & 0.125 & 48.79 & 256.78 \\
\hline \multirow{8}{*}{$\mathrm{CD}$} & \multirow{4}{*}{40} & 24 & 13.30 & 0.98 & 0.125 & 64.27 & 164.85 \\
\hline & & 60 & 12.84 & 0.99 & 0.125 & 69.91 & 177.63 \\
\hline & & 96 & 12.59 & 0.99 & 0.125 & 70.24 & 177.99 \\
\hline & & 132 & 12.13 & 0.99 & 0.125 & 76.45 & 178.19 \\
\hline & \multirow{4}{*}{45} & 24 & 10.65 & 1.00 & 0.125 & 80.35 & 210.79 \\
\hline & & 60 & 10.44 & 1.01 & 0.125 & 81.24 & 211.08 \\
\hline & & 96 & 10.10 & 1.01 & 0.125 & 88.77 & 211.20 \\
\hline & & 132 & 10.15 & 1.01 & 0.125 & 88.27 & 221.00 \\
\hline
\end{tabular}
and maximum drying rates of natural and pulped coffee as a function of temperature (Tem) and drying airflow. 
According to Table 1, an airflow of $24 \mathrm{~m}^{3} \mathrm{~min}^{-1}$ $\mathrm{m}^{-2}$ and increased temperatures $\left(40-45^{\circ} \mathrm{C}\right)$ reduced by 35 (73.20-47.93 hours) and 20\% (13.30-10.65 hours) drying times for natural and pulped coffee, respectively. An increased airflow (24-132 $\mathrm{m}^{3} \mathrm{~min}^{-1} \mathrm{~m}^{-2}$ ) for natural coffee provided reductions of 10 (73.20-66.10 hours) and 7\% (47.93-44.46 hours) in drying time for temperatures of 40 and $45{ }^{\circ} \mathrm{C}$, respectively. The same increase in airflow for pulped coffee provided reductions of 9 (13.30-12.13 hours) and 5\% (10.65-10.15 hours) for temperatures of 40 and $45^{\circ} \mathrm{C}$, respectively.

Santos et al. (2016) evaluated temperature influence on drying time in palm fruits and found that a temperature range between 50 and $70{ }^{\circ} \mathrm{C}$ decreased drying times from 720 to 540 minutes. Camicia et al. (2015) found a reduction in drying time for cowpeas from 10.4 to 2.1 hours for temperatures of 30 and $50{ }^{\circ} \mathrm{C}$, respectively. These results are in agreement with those obtained in our study. Siqueira et al. (2017) observed that the higher the temperature, the greater the difference between partial vapor pressure of dry air and the product, removing water easily and quickly.

The following factors are attributed to a reduction in drying time due to an increase in temperature: increased temperatures reduce water viscosity and directly influence fluid resistance to flow, while a decreased viscosity facilitates diffusion of water molecules through product capillaries (Corrêa et al., 2010; Tohidi et al., 2017; Araújo et al., 2017), in addition to providing an increase in water molecule vibration levels, which also contributes to increasing drying rates.

Figure 1 (a) and (b) show the drying rates as a function of moisture content in coffee fruits and parchment coffee submitted to complete drying in a dryer, respectively.

As shown in Figure 1 (a) and (b), decreased temperatures provide high drying rates for the same moisture content, and these different rates at different temperatures are high at the beginning of drying, and such differences decrease considerably as coffee fruits and parchment coffee get drier. Airflow effect for the same processing and temperature is more evident at the beginning of drying. As drying process progresses, water removal from coffee becomes more difficult due to a stronger connection between water and other bean constituents. Thus, drying rates for the four airflows and two temperatures tend to be similar or get closer at the end of the process.

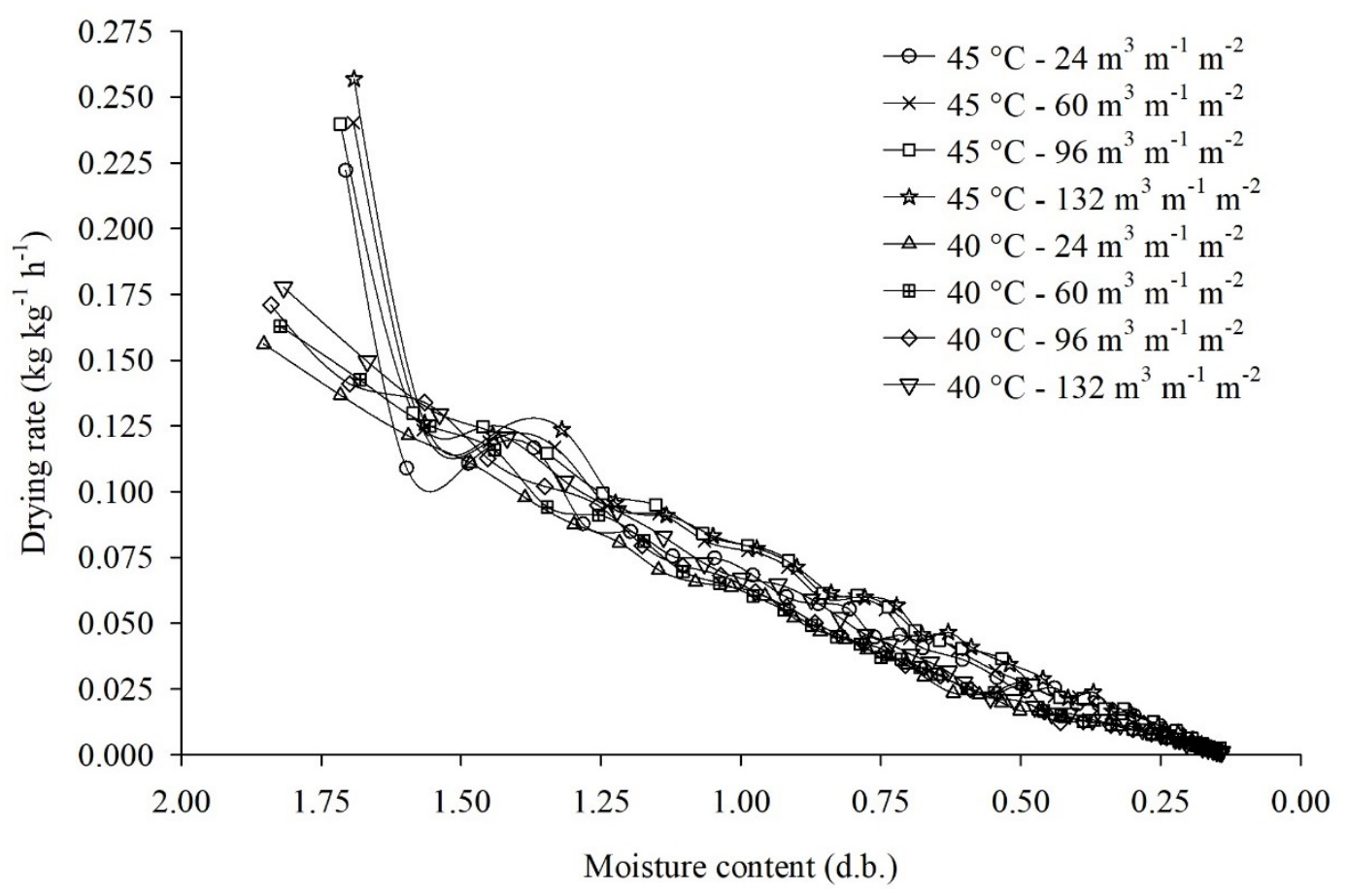

(a) 


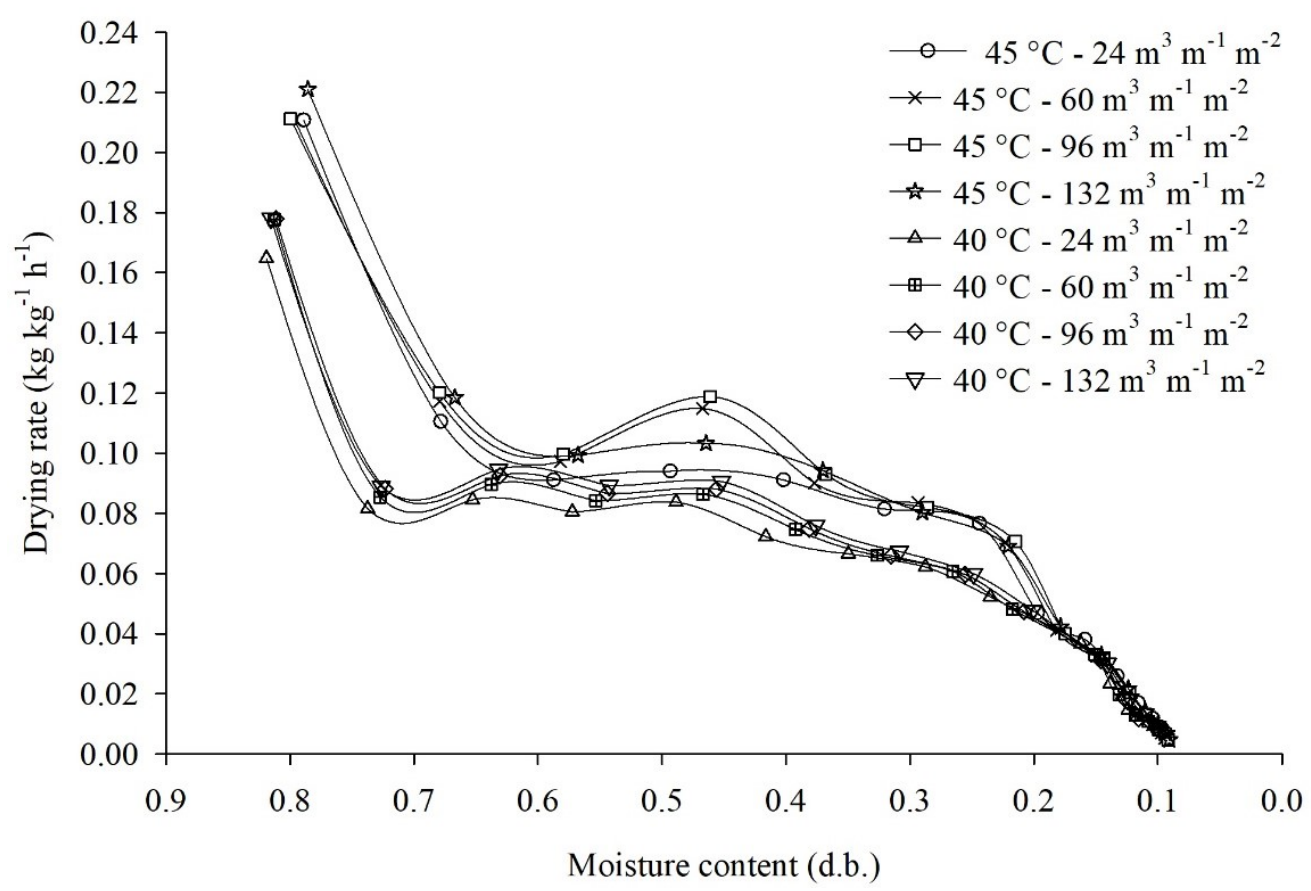

(b)

FIGURE 1. Drying rate as a function of moisture content in coffee fruits (a) and parchment coffee (b).

Drying rates of pulped coffee become slightly steady for moisture contents from 0.7 to $0.4(\mathrm{db})$. This behavior is related to a constant drying rate, as there is much free water in the surroundings of coffee beans before that interval, greatly increasing drying rates. However, the amount of water present in the product is much lower for the period after the above-mentioned interval, thus reducing drying rates.

Overall, water withdrawal speed from fruits decreases as drying progresses. This is because differences in heat and mass transfer between product and drying air are not compensated, and fruit temperature tends to increase, reaching a value close to that of drying air due to a high need for energy for evaporation of water, which is more strongly bonded (Alves et al., 2013; Siqueira et al., 2016, 2017).

Table 3 shows the statistical parameters for the eleven models used to describe drying kinetics of natural and pulped coffee, and respective coefficients of determination $\left(\mathrm{r}^{2}\right)$, standard deviation of estimates (SD), and relative mean error $(\mathrm{P})$. The mean initial moisture content was 2.07 and $1.00 \mathrm{~kg}$ water $\mathrm{kg}^{-1}$ dry matter $(\mathrm{db})$ for natural and pulped coffee, respectively, after subjected to both temperatures and the four airflows. 
TABLE 3. Coefficients of determination $\left(\mathrm{r}^{2}\right)$, standard deviation of estimates (SD), and relative mean error (P) for the models used to describe drying kinetics of natural and pulped coffee under different temperatures and airflows.

\begin{tabular}{|c|c|c|c|c|c|c|c|c|c|c|c|c|}
\hline \multicolumn{13}{|c|}{ Pulped coffee $\left(40^{\circ} \mathrm{C}\right)$} \\
\hline \multirow{3}{*}{ Model } & \multicolumn{12}{|c|}{ Airflow $\left(\mathrm{m}^{3} \min ^{-1} \mathrm{~m}^{-2}\right)$} \\
\hline & \multicolumn{3}{|c|}{24} & \multicolumn{3}{|c|}{60} & \multicolumn{3}{|c|}{96} & \multicolumn{3}{|c|}{132} \\
\hline & $\mathrm{SD}$ & P (\%) & $r^{2}(\%)$ & $\mathrm{SD}$ & $\mathrm{P}(\%)$ & $r^{2}(\%)$ & $\mathrm{SD}$ & P (\%) & $r^{2}(\%)$ & $\mathrm{SD}$ & $\mathrm{P}(\%)$ & $r^{2}(\%)$ \\
\hline 6 & 0.03 & 29.57 & 99.47 & 0.04 & 48.03 & 98.67 & 0.04 & 50.66 & 98.74 & 0.03 & 12.10 & 99.48 \\
\hline 7 & 0.04 & 68.18 & 98.32 & 0.04 & 51.16 & 98.59 & 0.04 & 54.14 & 98.65 & 0.04 & 25.31 & 98.58 \\
\hline 8 & 0.02 & 23.36 & 99.71 & 0.08 & 46.47 & 94.04 & 0.09 & 38.27 & 95.03 & 0.02 & 4.57 & 99.79 \\
\hline 9 & 0.04 & 63.22 & 98.46 & 0.04 & 48.03 & 98.67 & 0.04 & 50.67 & 98.74 & 0.04 & 24.00 & 98.66 \\
\hline 10 & 0.02 & 19.61 & 99.68 & 0.02 & 15.29 & 99.69 & 0.02 & 15.94 & 99.70 & 0.02 & 6.61 & 99.74 \\
\hline 11 & 0.04 & 68.18 & 98.32 & 0.04 & 51.16 & 98.59 & 0.04 & 54.14 & 98.65 & 0.04 & 25.31 & 98.58 \\
\hline 12 & 0.03 & 29.01 & 99.33 & 0.03 & 23.33 & 99.35 & 0.03 & 23.93 & 99.41 & 0.03 & 12.97 & 99.31 \\
\hline 13 & 0.04 & 68.18 & 98.32 & 0.04 & 51.15 & 98.59 & 0.04 & 54.15 & 98.65 & 0.04 & 25.32 & 98.58 \\
\hline 14 & 0.03 & 31.43 & 99.40 & 0.02 & 23.88 & 99.44 & 0.04 & 54.14 & 98.65 & 0.03 & 12.72 & 99.41 \\
\hline 15 & 0.02 & 13.98 & 99.72 & 0.02 & 12.53 & 99.64 & 0.02 & 15.84 & 99.65 & 0.02 & 2.73 & 99.69 \\
\hline 16 & 0.01 & 6.78 & 99.87 & 0.01 & 4.43 & 99.85 & 0.01 & 5.71 & 99.87 & 0.01 & 3.21 & 99.84 \\
\hline 17 & 0.01 & 3.85 & 99.88 & 0.01 & 5.85 & 99.86 & 0.01 & 5.20 & 99.87 & 0.01 & 3.17 & 99.85 \\
\hline \multicolumn{13}{|c|}{ Pulped coffee $45^{\circ} \mathrm{C}$} \\
\hline 6 & 0.03 & 37.23 & 99.38 & 0.02 & 23.48 & 99.60 & 0.02 & 30.35 & 99.60 & 0.02 & 38.94 & 99.53 \\
\hline 7 & 0.04 & 76.11 & 98.65 & 0.02 & 29.03 & 99.51 & 0.02 & 37.38 & 99.52 & 0.03 & 83.47 & 98.91 \\
\hline 8 & 0.12 & 128.02 & 90.73 & 0.04 & 56.92 & 98.95 & 0.02 & 36.60 & 99.68 & 0.15 & 205.23 & 84.59 \\
\hline 9 & 0.04 & 72.50 & 98.70 & 0.03 & 56.93 & 98.95 & 0.03 & 72.78 & 98.90 & 0.03 & 79.41 & 98.96 \\
\hline 10 & 0.02 & 29.24 & 99.57 & 0.02 & 21.58 & 99.66 & 0.02 & 26.21 & 99.67 & 0.02 & 32.76 & 99.64 \\
\hline 11 & 0.04 & 76.11 & 98.65 & 0.03 & 61.01 & 98.88 & 0.03 & 78.32 & 98.81 & 0.03 & 83.45 & 98.91 \\
\hline 12 & 0.03 & 38.50 & 99.23 & 0.02 & 24.27 & 99.49 & 0.02 & 30.12 & 99.51 & 0.03 & 41.11 & 99.40 \\
\hline 13 & 0.04 & 76.11 & 98.65 & 0.03 & 61.03 & 98.88 & 0.04 & 78.35 & 98.81 & 0.03 & 83.47 & 98.91 \\
\hline 14 & 0.04 & 76.10 & 98.65 & 0.02 & 27.14 & 99.68 & 0.04 & 78.35 & 98.81 & 0.02 & 32.38 & 99.69 \\
\hline 15 & 0.03 & 33.09 & 99.37 & 0.03 & 42.01 & 99.40 & 0.03 & 56.64 & 99.42 & 0.03 & 61.99 & 99.21 \\
\hline 16 & 0.02 & 7.99 & 99.79 & 0.01 & 12.12 & 99.85 & 0.01 & 16.85 & 99.85 & 0.01 & 12.18 & 99.84 \\
\hline 17 & 0.02 & 7.81 & 99.76 & 0.01 & 7.48 & 99.84 & 0.01 & 7.81 & 99.86 & 0.02 & 3.40 & 99.82 \\
\hline \multicolumn{13}{|c|}{ Natural coffee $40^{\circ} \mathrm{C}$} \\
\hline 6 & 0.01 & 2.43 & 99.95 & 0.01 & 4.23 & 99.93 & 0.01 & 2.99 & 99.96 & 0.01 & 3.87 & 99.94 \\
\hline 7 & 0.02 & 18.00 & 99.42 & 0.04 & 34.88 & 97.21 & 0.02 & 19.60 & 99.47 & 0.02 & 23.40 & 99.26 \\
\hline 8 & 0.01 & 1.61 & 99.96 & 0.00 & 2.63 & 99.99 & 0.00 & 2.05 & 100.00 & 0.01 & 3.87 & 99.94 \\
\hline 9 & 0.03 & 24.46 & 98.63 & 0.03 & 25.85 & 98.66 & 0.03 & 26.55 & 98.67 & 0.03 & 29.56 & 98.46 \\
\hline 10 & 0.01 & 2.45 & 99.96 & 0.00 & 1.08 & 99.99 & 0.00 & 2.21 & 99.98 & 0.01 & 2.66 & 99.96 \\
\hline 11 & 0.04 & 32.92 & 97.28 & 0.04 & 34.88 & 97.21 & 0.04 & 34.80 & 97.44 & 0.04 & 38.02 & 97.07 \\
\hline 12 & 0.01 & 4.30 & 99.94 & 0.00 & 4.80 & 99.96 & 0.01 & 5.52 & 99.95 & 0.01 & 6.62 & 99.92 \\
\hline 13 & 0.01 & 4.14 & 99.92 & 0.01 & 3.59 & 99.90 & 0.01 & 3.12 & 99.95 & 0.01 & 3.17 & 99.93 \\
\hline 14 & 0.01 & 3.11 & 99.91 & 0.04 & 34.88 & 97.21 & 0.01 & 4.21 & 99.93 & 0.04 & 38.02 & 97.07 \\
\hline 15 & 0.12 & 87.40 & 78.66 & 0.12 & 98.53 & 76.07 & 0.12 & 101.93 & 76.40 & 0.13 & 114.05 & 72.19 \\
\hline 16 & 0.02 & 11.59 & 99.65 & 0.02 & 11.82 & 99.61 & 0.02 & 13.14 & 99.61 & 0.02 & 16.08 & 99.45 \\
\hline 17 & 0.01 & 2.04 & 99.96 & 0.01 & 2.54 & 99.93 & 0.01 & 1.60 & 99.98 & 0.01 & 2.69 & 99.96 \\
\hline \multicolumn{13}{|c|}{ Natural coffee $45^{\circ} \mathrm{C}$} \\
\hline 6 & 0.01 & 1.78 & 99.96 & 0.01 & 2.06 & 99.96 & 0.01 & 2.22 & 99.95 & 0.01 & 2.22 & 99.94 \\
\hline 7 & 0.01 & 2.46 & 99.94 & 0.02 & 12.73 & 99.26 & 0.01 & 3.25 & 99.93 & 0.02 & 17.10 & 99.07 \\
\hline 8 & 0.01 & 1.78 & 99.96 & 0.01 & 2.06 & 99.96 & 0.00 & 1.48 & 99.99 & 0.00 & 0.86 & 100.00 \\
\hline 9 & 0.02 & 11.35 & 99.61 & 0.01 & 8.01 & 99.71 & 0.02 & 12.02 & 99.56 & 0.02 & 12.15 & 99.57 \\
\hline 10 & 0.00 & 1.04 & 99.98 & 0.00 & 1.24 & 99.98 & 0.00 & 1.07 & 99.98 & 0.00 & 0.83 & 99.98 \\
\hline 11 & 0.02 & 15.96 & 99.17 & 0.02 & 12.73 & 99.26 & 0.02 & 17.06 & 99.05 & 0.02 & 17.10 & 99.07 \\
\hline 12 & 0.00 & 2.84 & 99.97 & 0.00 & 1.45 & 99.98 & 0.00 & 2.91 & 99.97 & 0.01 & 3.88 & 99.95 \\
\hline 13 & 0.01 & 1.82 & 99.94 & 0.01 & 3.17 & 99.90 & 0.01 & 2.11 & 99.93 & 0.01 & 2.14 & 99.91 \\
\hline 14 & 0.01 & 2.53 & 99.94 & 0.01 & 2.59 & 99.95 & 0.01 & 3.17 & 99.93 & 0.01 & 4.07 & 99.90 \\
\hline 15 & 0.08 & 45.58 & 91.63 & 0.07 & 36.89 & 93.38 & 0.08 & 46.94 & 91.04 & 0.08 & 47.22 & 90.98 \\
\hline 16 & 0.01 & 3.10 & 99.96 & 0.01 & 2.42 & 99.96 & 0.01 & 3.37 & 99.95 & 0.01 & 2.55 & 99.95 \\
\hline 17 & 0.01 & 1.67 & 99.97 & 0.01 & 1.94 & 99.97 & 0.01 & 1.95 & 99.96 & 0.01 & 2.67 & 99.94 \\
\hline
\end{tabular}


The analysis of statistical parameters was performed separately for each type of processing due to high differences in drying kinetics of natural and pulped coffee.

The analysis of a single parameter is not a useful tool for evaluation of non-linear models, requiring a joint analysis of parameters: coefficient of determination, standard deviation of estimate, and relative mean error. The ability of a model to accurately describe a particular physical process is inversely proportional to the standard deviation of estimates. Relative mean errors below 10\% are recommended (Madamba et al., 1996; Mohapatra \& Rao, 2005).

Regarding the coefficients of determination $\left(r^{2}\right)$ of pulped coffee, both Valcam (16) and Proposed Model (17) presented the highest values (above 99.76\%). Natural processed coffee presented a coefficient of determination $\left(r^{2}\right)$ higher than $97.07 \%$ for almost all models used, except for Wang and Sing model (15), which, according to Madamba et al. (1996), is a value considered acceptable to describe drying phenomena.

Considering the criterion of relative mean errors $(\mathrm{P})$ below $10 \%$ for acceptable fit, the results obtained for pulped coffee showed that only the Proposed Model (17) presented a satisfactory fit for dry coffee at $45{ }^{\circ} \mathrm{C}$ $(\mathrm{P}<7.81 \%)$, and the best value of relative mean error for dry coffee at $40{ }^{\circ} \mathrm{C}(\mathrm{P}<5.85 \%)$. Additionally, the models two-term (6), modified Henderson \& Pabis (8), Midilli
(10), Page (12), Thompson (13), and Proposed Model (17) had relative mean errors lower than $10 \%$ for natural coffee, and they can also be used in other applications.

All models used presented $\mathrm{SD}<0.05$, except for the modified Henderson \& Pabis (8) and Wang and Sing (15) models.

Regarding the behavior (or trend) of distribution of residuals for the studied models, the models Valcam (16) for pulped coffee, Midilli (10) for natural coffee, and Proposed Model (17) had a random distribution of residuals for all studied conditions.

Among the models used in this study to describe the drying process of pulped coffee and considering the analysis of coefficients of determination, relative mean errors, standard deviations of estimates, and trend of distribution of residuals, the Proposed Model (17) presented the best fit. The models showing the best fit for natural coffee were Midilli (10) and Proposed Model (17), also considering the same evaluation parameters.

The Proposed Model (17) was adopted to represent drying kinetics of natural and pulped coffees under the conditions considered in this study due to its satisfactory fit under all drying conditions and ease of use.

Table 4 shows the coefficients of the Proposed Model for natural and pulped coffee, fitted to the observed data of thin-layer drying kinetics under the conditions considered in this experiment.

TABLE 4. Proposed Model coefficients fitted to the thin-layer drying characteristics of natural and pulped coffee.

\begin{tabular}{|c|c|c|c|c|c|c|c|}
\hline \multirow{2}{*}{ Processing } & \multirow{2}{*}{$\begin{array}{c}\text { Temperature } \\
\left({ }^{\circ} \mathrm{C}\right)\end{array}$} & \multirow{2}{*}{$\begin{array}{c}\text { Airflow } \\
\left(\mathrm{m}^{3} \min ^{-1} \mathrm{~m}^{-2}\right)\end{array}$} & \multicolumn{5}{|c|}{ Model coefficient } \\
\hline & & & $\mathrm{a}$ & $\mathrm{b}$ & $\mathrm{k}_{0}$ & $\mathrm{k}_{1}$ & $\mathrm{~N}$ \\
\hline \multirow{8}{*}{ Natural } & \multirow{4}{*}{40} & 24 & 33.3836 & 33.1341 & -15.5549 & 44.3614 & 0.0083 \\
\hline & & 60 & 46.0625 & 46.0433 & -0.3655 & 0.9937 & 0.3984 \\
\hline & & 96 & 33.8310 & 33.5280 & -18.1085 & 47.3185 & 0.0080 \\
\hline & & 132 & 60.2551 & 60.3382 & -1.7779 & 5.1655 & 0.0861 \\
\hline & \multirow{4}{*}{45} & 24 & 0.1086 & -0.8896 & -0.7714 & 0.1474 & 0.0480 \\
\hline & & 60 & 0.7720 & -0.2166 & 1.1412 & 2.3307 & 0.0510 \\
\hline & & 96 & 0.1208 & -0.8770 & -0.4736 & 0.1119 & 0.0720 \\
\hline & & 132 & 0.0916 & -0.9066 & -0.2470 & 0.0402 & 0.1532 \\
\hline \multirow{8}{*}{ Pulped } & \multirow{4}{*}{40} & 24 & 0.3742 & -0.6176 & 0.0863 & 0.4642 & 0.0885 \\
\hline & & 60 & 0.3402 & -0.6503 & 0.0370 & 0.3516 & 0.1082 \\
\hline & & 96 & 0.3101 & -0.6839 & 0.0036 & 0.2948 & 0.1138 \\
\hline & & 132 & 0.2371 & -0.7575 & -0.0316 & 0.1994 & 0.1340 \\
\hline & \multirow{4}{*}{45} & 24 & 18.1339 & 17.6652 & -22.3481 & 52.5765 & 0.0072 \\
\hline & & 60 & 17.3364 & 16.6682 & -23.0004 & 52.5763 & 0.0075 \\
\hline & & 96 & 21.1488 & 20.5184 & -21.9210 & 52.5764 & 0.0081 \\
\hline & & 132 & 20.4160 & 19.8862 & -23.7046 & 52.5764 & 0.0076 \\
\hline
\end{tabular}

Figures 2 and 3 show the behavior of the moisture ratio observed and estimated by the Proposed Model (17) for natural and pulped coffee dried at 40 and $45{ }^{\circ} \mathrm{C}$ in a thin layer. The high agreement between the moisture ratios obtained experimentally and those estimated by the Proposed Model for all studied conditions confirms the satisfactory fit of this model to describe drying kinetics for each type of processing under the studied conditions. 


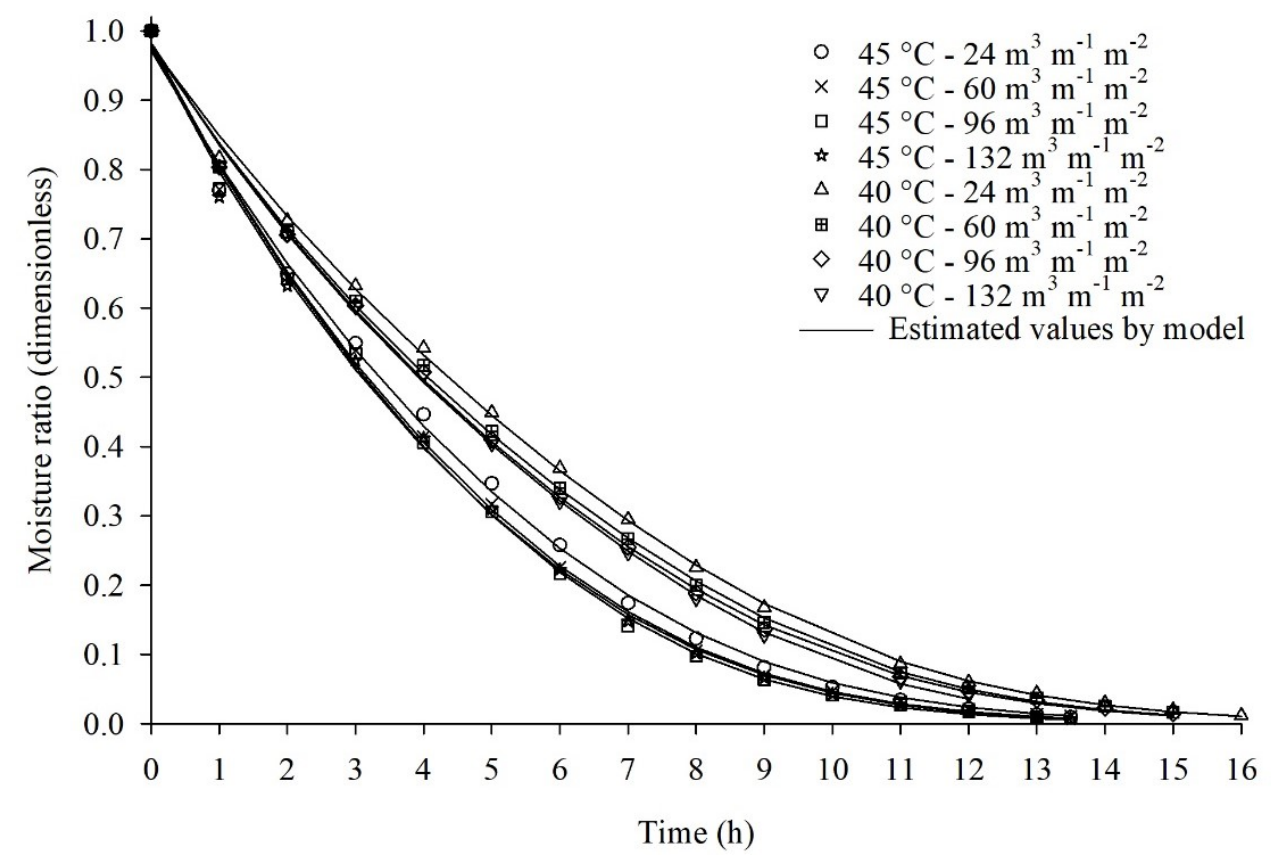

(a)

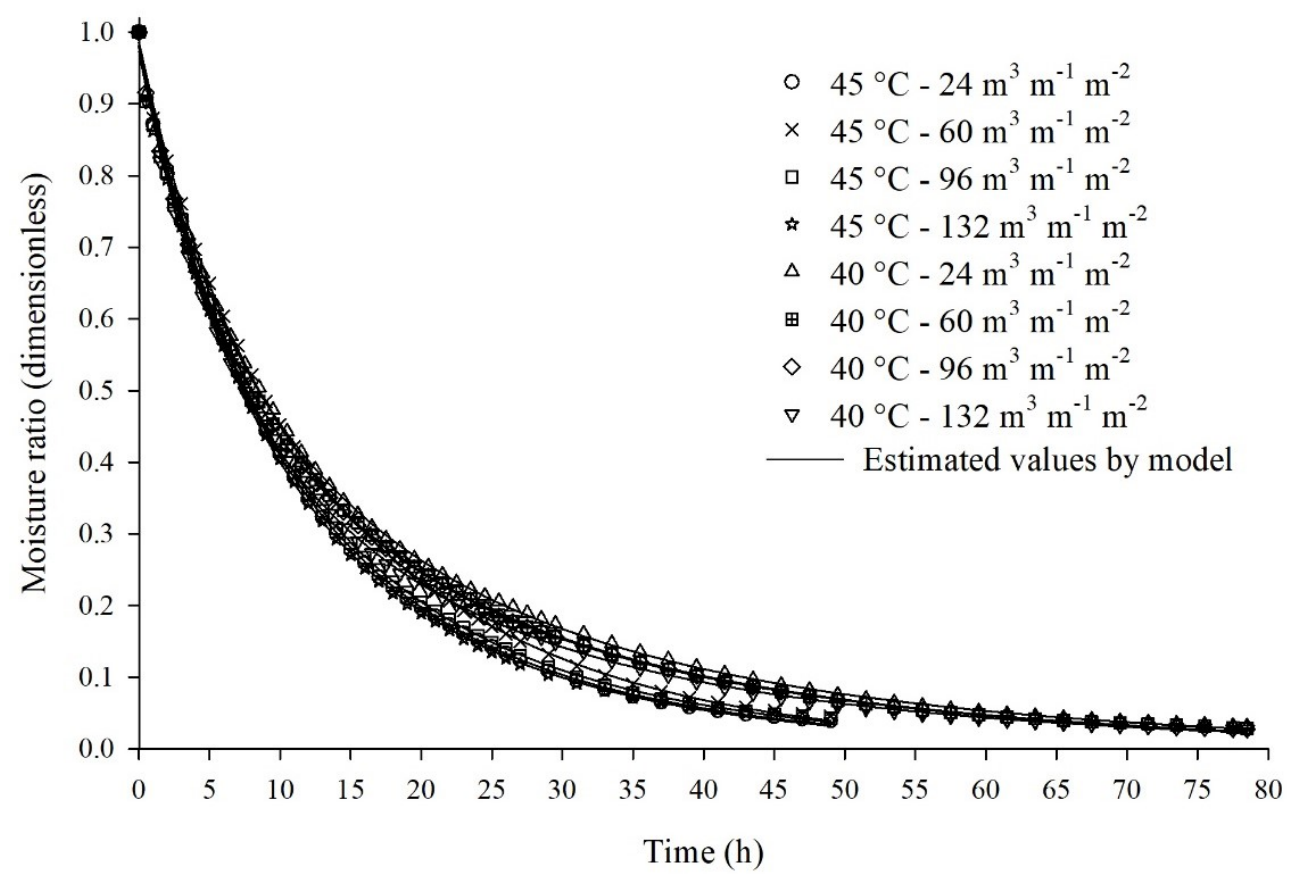

(b)

FIGURE 2. Moisture ratios observed and estimated by the Proposed Model for drying pulped (a) and natural (b) coffee as a function of time.

Table 5 shows the splitting of drying treatment effects for each temperature and airflow on the drying times of pulped and natural coffee. A significant interaction was observed between temperatures and drying airflows only for pulped coffee. Therefore, we presented means of natural coffee treatments and their comparisons with means of temperature and airflow.

Regarding the airflows for both drying temperatures, a flow of $24 \mathrm{~m}^{3} \mathrm{~min}^{-1} \mathrm{~m}^{-2}$ had the longest drying times for pulped and natural coffee. But at $45{ }^{\circ} \mathrm{C}$, no significant differences were observed when compared to a flow of 60 $\mathrm{m}^{3} \mathrm{~min}^{-1} \mathrm{~m}^{-2}$ for both pulped and natural coffee.

Significant differences were observed between temperatures for all airflows in CD processing. The two highest flows, however, did not differ from each other for a temperature of $40^{\circ} \mathrm{C}$, which was also seen for the three highest flows at $45^{\circ} \mathrm{C}$. In this sense, flows of 96 and 132 $\mathrm{m}^{3} \mathrm{~min}^{-1} \mathrm{~m}^{-2}$ are recommended to speed up drying process regardless of the air temperature. 
TABLE 5. Means of drying time (hours) until coffee beans reach $0.125 \pm 0.005 \mathrm{~kg}$ water kg${ }^{-1}$ dry matter (db) for natural (NAT) and pulped $(\mathrm{CD})$ coffee as a function of airflow and temperature.

\begin{tabular}{ccccccc}
\hline \multirow{2}{*}{ Processing } & \multirow{2}{*}{$\begin{array}{c}\text { Temperature } \\
\left({ }^{\circ} \mathrm{C}\right)\end{array}$} & \multicolumn{4}{c}{$\begin{array}{c}\text { Airflow } \\
\left(\mathrm{m}^{3} \mathrm{~min}^{-1} \mathrm{~m}^{-2}\right)\end{array}$} & \multirow{2}{*}{ Mean } \\
\cline { 3 - 6 } & & 24 & 60 & 96 & 132 & \\
\cline { 3 - 6 } $\mathrm{CD}$ & 40 & $13.30 \mathrm{aA}$ & $12.84 \mathrm{aB}$ & $12.59 \mathrm{aC}$ & $12.13 \mathrm{aC}$ \\
& 45 & $10.65 \mathrm{bA}$ & $10.44 \mathrm{bAB}$ & $10.10 \mathrm{bB}$ & $10.15 \mathrm{bB}$ & \\
\hline \multirow{2}{*}{ NAT } & 40 & 73.20 & 71.06 & 67.92 & 66.10 & $69.57 \mathrm{a}$ \\
& 45 & 47.93 & 45.84 & 44.08 & 44.46 & $45.58 \mathrm{~b}$ \\
\cline { 2 - 6 } & Mean & $60.57 \mathrm{~A}$ & $58.45 \mathrm{AB}$ & $56.00 \mathrm{BC}$ & $55.28 \mathrm{C}$ & \\
\hline
\end{tabular}

Means followed by different lowercase letters in the columns and uppercase letters in the rows differ from each other for each type of coffee by Tukey's test at $5 \%$ probability.

\section{CONCLUSIONS}

The Proposed Model presented the best fit to natural and pulped coffee drying data at drying air temperatures of 40 and $45{ }^{\circ} \mathrm{C}$ and airflows from 24 to 132 $\mathrm{m}^{3} \min ^{-1} \mathrm{~m}^{-2}$.

Temperature and air-flow rises increase coffee drying rates and thereby reduce drying times.

The shortest drying times can be achieved at $45{ }^{\circ} \mathrm{C}$ and at 96 and $132 \mathrm{~m}^{3} \mathrm{~min}^{-1} \mathrm{~m}^{-2}$ regardless of the coffee processing type.

\section{REFERENCES}

Alves GE, Isquierdo EP, Borém FM, Siqueira VC, Oliveira PD, Andrade ET (2013) Drying kinetics of natural coffee for different temperatures and low relative humidity. Coffee Science 8(2):226-236.

Afonso Júnior PC (2001) Aspectos físicos, fisiológicos e de qualidade do café em função da secagem e do armazenamento. Tese Doutorado, Viçosa, Universidade Federal de Viçosa.

Araújo WD, Goneli ALD, Corrêa PC, Filho CPH, Martins EAS (2017) Modelagem matemática da secagem dos frutos de amendoim em camada delgada. Revista Ciência Agronômica 48(3):448-457.

Avhad MR, Marchetti JM (2016) Mathematical modelling of the drying kinetics of Hass avocado seeds. Industrial Crops and Products 91:76-87.

Borém FM (2013) Handbook of coffee post-harvest technology. Norcross, Gin.

Brasil. Ministério da Agricultura, Pecuária e Abastecimento (2009) Regras para análise de sementes. Brasília, 399 p.

Camicia RGM, Christ D, Coelho SRM, Camicia RFM (2015) Modelagem do processo de secagem de sementes de feijão-caupi. Revista Caatinga 28(3):206-214.

Corrêa PC, Botelho FM, Botelho SCC, Goneli ALD (2014) Isotermas de sorção de água de frutos de Coffea canephora. Revista Brasileira de Engenharia Agrícola e Ambiental 18(10):1047-1052.

Corrêa PC, Oliveira GHH, Botelho FM, Goneli ALD, Carvalho FM (2010) Modelagem matemática e determinação das propriedades termodinâmicas do café (Coffea arabica L.) durante o processo de secagem.

Revista Ceres 57(5):595-601.
Ferreira DF (2011) Sisvar: a computer statistical analysis system. Ciência e Agrotecnologia 35:1039-1042.

Goneli ALD, Corrêa P, Afonso Junior PC, Oliveira GHH (2009) Cinética de secagem dos grãos de café descascados em camada delgada. Revista Brasileira de Armazenamento 11:64-73.

ISO - International Organization for Standardization (2003) Green coffee: determination of loss in mass at $105^{\circ} \mathrm{C}$ : ISO 6673. ISO, $17 \mathrm{p}$.

Isquierdo EP (2013) Drying kinetics and quality of natural coffee. Transactions of the ASAE 53(3):1003-1010.

Madamba PS, Driscoll RH, Buckle KA (1996) Thin-layer drying characteristics of garlic slices. Journal of Food Engineering 29(1):75-97.

Mohapatra D, Rao PS (2005) A thin layer drying model of parboiled wheat. Journal of Food Engineering 66(4):513-518.

Resende O, Arcanjo RV, Siqueira VC, Rodrigues S (2009) Modelagem matemática para a secagem de clones de café (Coffea canephora Pierre) em terreiro de concreto. Acta Scientiarum Agronomy 31(2):189-196.

Santos AE, Martins GMV, Canuto MFCS, Vieira Segundo JED, Almeida RD (2016) Modelagem matemática para a descrição da cinética de secagem do fruto da palma (Opuntia fícus indica). Revista Verde de Agroecologia e Desenvolvimento Sustentável 11(1):1-6.

Siqueira VC, Borém FM, Alves GE, Isquierdo EP, Pinto ACF, Ribeiro DE, Ribeiro FC (2017) Drying kinetics of processed natural coffee with high moisture content. Coffee Science 12(3):400-409.

Siqueira VC, Borém FM, Isquierdo EP, Alves GE, Ribeiro DE, Pinto ACF, Taveira JHS (2016) Drying of hulled naturally processed coffee with high moisture content and its impacts on quality. African Journal of Agricultural Research 11(31):2903-2911.

Siqueira VC, Resende O, Chaves TH (2013) Mathematical modelling of the drying of Jatropha fruit: an empirical comparison. Revista Ciência Agronômica 44(2):278-285.

Tohidi M, Sadeghi M, Torki-Harchegani M (2017) Energy and quality aspects for fixed deep bed drying of paddy. Renewable and Sustainable Energy Reviews 70:519-528. 